\title{
The Suitability of 42SiCr Steel for Quenching and Partitioning Process
}

Ludmila Kučerová, Hana Jirková, Josef Káňa

RTI, UWB in Pilsen, Universitni 8, 30614 Pilsen, Czech Republic. E-mail: skal@rti.zcu.cz, h.jirkova@email.cz, jkana@rti.zcu.cz

QP (quenching and partitioning) heat and thermo-mechanical treatment was applied to middle carbon, low alloyed $\mathrm{CMnSiCr}$ steel. Various numbers of deformation steps and different heating and cooling rates were tested for this steel. Two QP treatments were accompanied by subsequent annealing step at $250^{\circ} \mathrm{C}$ (QP-T processing). The effect of several processing strategies on mechanical properties and microstructures was determined by tensile tests and microstructure analysis was carried out by the means of scanning electron microscopy. Volume fraction of retained austenite was further established by $\mathrm{X}$-ray diffraction phase analysis. The final microstructures were mostly martensitic with $\mathbf{1 8 - 2 4 \%}$ of retained austenite and small amounts of fine bainite. High strengths above 1900 MPa were obtained for all of the treatments with ductility $A_{5 \mathrm{~mm}}$ in the range of 12-19\%.

Keywords: QP process, partitioning hold, retained austenite, chromium

\section{Acknowledgement}

The present contribution has been prepared under project LO1502 'Development of the Regional Technological Institute' under the auspices of the National Sustainability Programme I of the Ministry of Education of the Czech Republic aimed to support research, experimental development and innovation.

\section{References}

[1] WASSERMANN, G. (1937). Untersuchungen an einer Eisen-Nickel-Legierung über die Verformbarkeit während der $\gamma$ - $\alpha$-Umwandlung. In: Arch. Eisenhutten., Vol. 10, No. 7, pp. 321-25.

[2] KUČEROVÁ, L., JIRKOVÁ, H., MAŠEK, B. (2016). Influence of Nb Micro-alloying on TRIP Steels Treated by Continuous Cooling Process. In: Manufacturing Technology, Vol. 16, No. 1, pp. 145-149.

[3] CHEN, C. Y., CHEN, C. C., LIN, J. S. (2014). Morphology Feature of Nanostructure Bainitic Steel after Tempering Treatment. In: International Journal of Mechanical, Aerospace, Industrial, Mechatronic and Manufacturing Engineering, Vol. 8, No. 5, pp. 928-931.

[4] HANUS, P., SCHMIDOVÁ, E. (2016). Influence of the Welding Process on the Martensitic and Dual Phase High Strength Steels. In:Manufacturing Technology, Vol. 16, No. 4, pp. 702-707.

[5] ROSENBERG, G., SINAIOVÁ, I., JUHÁR, L. (2012). Influence of microstructural heterogeneities on capacity to absorb energy of dual-phase steels. In: Manufacturing Technology, Vol. 12, No. 13, pp. 222-227.

[6] EDMONDS, D. V., et al. (2006). Quenching and partitioning martensite - a novel steel heat treatment. In: Mater. Sci. Eng. A, Vols. 438-440, pp. 25-34.

[7] KUČEROVÁ, L. et al. (2014). The Effect of alloying on Mechanical Properties of Advanced High Strength Steels. In: Archives of Metallurgy and Materials. Vol. 59, No. 3, pp. 1189-1192.

[8] LI, G. Y., et al. (2015). New Process of Hot Stamping in Combination with Q-P-T Treatment for Higher StrengthDuctility Auto-Parts. In: Advanced Materials Research, Vol. 1063, pp. 223-231.

[9] G. GAO et al. (2015). Tempering Behavior of Ductile 1700 MPa Mn-Si-Cr-C Steel. In: J. Mater. Sci. Technol., Vol. 31, No. 2, pp. 199-204.

[10] XU, Y., et al. (2014). Microstructure evolution and mechanical properties of a hot-rolled directly quenched and partitioned steel containing proeutectoid ferrite. In: Mat. Sci. Eng. A 607, pp. 460-475.

[11] DOAN, V. T., KUSMIC, D., POSPICHAL, M. (2015), Surface Treatment Technologies for Wear Resistance Increasing of 42CrMo4 Steel, In: Manufacturing Technology, Vol. 15, No. 3, pp. 703-707.

[12] KUČEROVÁ, L., et al. (2011). Mikrostrukturní rozbor oceli 42SiCr zpracované Q-P procesem. In: Strojírenská technologie časopis pro vědu, výzkum a výrobu, Vol. 16, No. 1, pp. 49-54.

[13] MAŠEK, B., et al. (2007). Physical Modelling of Microstructure Development during Technological Processes with Intensive Incremental Deformation. In: Mechanical Behavior of Materials X, Vols. 345-346, pp. 943-946.

[14] ZHONG, N.. et al. (2009). Enhancement of the mechanical properties of a Nb-microalloyed advanced high-strength steel treated by quenching-partitioning-tempering process. In: Mater. Sci. Eng. A, Vol. 506, pp. 111-116.

[15] WANG, X. D., et al. (2010). Carbide characterization in a Nb-microalloyed advanced ultrahigh strength steel after quenching-partitioning-tempering process. In: Mater. Sci. Eng. A, Vol. 527, pp. 3373-3378. 